\title{
Vidékfejlesztés Magyarországon: mérföldkövek egy göröngyös úton
}

\author{
Rural development in Hungary: milestones on a rugged road \\ KULCSÁR LÁSZLÓ
}

\begin{abstract}
KULCSÁR László: professzor emeritus, Soproni Egyetem, Lámfalussy Sándor Közgazdaságtudományi Kar; 9400 Sopron, Erzsébet u. 9.; la.kulcsar@gmail.com; https://orcid.org/ 0000-0002-5684-382X
\end{abstract}

KULCSSZAVAK: vidékfejlesztés; SAPARD; LEADER; társadalmi innováció; jó gyakorlatok

László KULCSÁR: professor emeritus, Alexander Lámfalussy Faculty of Economics, University of Sopron; Erzsébet u. 9., H-9400 Sopron, Hungary; la.kulcsar@gmail.com; https://orcid.org/00000002-5684-382X

KEYWORDS: rural development; SAPARD; LEADER; social innovation; best practices

Az elmúlt 20-30 évet tekintve vidéken a legfontosabb változást kétségtelenül a rendszerváltozás által keltett folyamatok jelentették. Ezek a folyamatok „elhúzták a függönyt" a társadalmi-gazdasági egyenlőtlenségek elől, azaz nyilvánvalóvá váltak a hatalmas szociális, kulturális és regionális különbségek az egyes vidéki területek között. Ezek az egyenlőtlenségek máig fennállnak, sőt azt mondhatjuk, hogy a differenciálódás erősödött, vagyis egyes térségek előnyösebb helyzetbe kerültek, míg mások próbálkozásaik ellenére sem tudtak helyzetükön lényegesen változtatni (Uzzoli, Szilágyi 2013; Nemes-Nagy 2017). A vidéki területek regionális egyenlőtlenségei, amelyek a 19. század második felében mutatkoztak meg erőteljesen a gazdasági, társadalmi átalakulás hatására, máig jelen vannak. A mai állapotok tehát nemcsak a szocializmus vagy a rendszerváltás hatásaként keletkeztek, de kétségtelen, hogy a rendszerváltozás után tűntek fel drámai erővel.

Éppen ezért füződött az Európai Unióhoz való csatlakozáshoz olyan sok remény, mivel a vidéki térségek lakossága komoly változást remélt a csatlakozástól. G. Fekete Éva is ezt remélte, és nem rajta múlott, hogy ez nem következett be (G. Fekete 2005). A csatlakozás előtti SAPARD programra is azért kell visszautalni, mert akkor vált világossá, egyértelművé, hogy a csatlakozás nem fogja meghozni a várt felemelkedést a történelmileg is hátrányos helyzetben lévő térségeknek (Kulcsár et al. 2003).

A SAPARD programra való felkészülést óriási érdeklődés és remény övezte. Megindultak a kistérségi szerveződések, s ez komoly előnnyel kecsegtetett a vidéki társadalom demokratizálódása, a szubszidiaritás térhódítása szempontjából. A

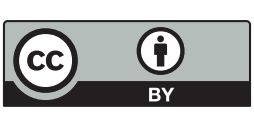


SAPARD vidékfejlesztési képzésen, amelyet volt szerencsém irányítani, több mint 500 személy vett részt az ország szinte minden térségéből. A képzés erőteljesen közösségi megközelítésű volt, s a vidéki gazdaság diverzifikációját, a helyi szereplők, közösségek aktív részvételét szorgalmazta (Kulcsár 1999). Sajnos hamar kiderült, hogy a folyamatok a különböző érdekcsoportok nyomására más irányt vettek. Így például a közösségfejlesztést is magába foglaló diverzifikált gazdasági és társadalomfejlesztési kezdeményezések lassan elhalványultak, és előtörtek a szinte kizárólag agrárérdekeket képviselő programok. Más oldalról pedig a kísérleti LEADER program akciócsoportjaiban a három kulcsszereplö (önkormányzat, vállalkozók, civil szervezetek) között megkívánt egyensúly sok esetben nem volt megvalósítható, vagy rövid idő után felborult. A partneri viszonyok helyett elötérbe kerültek a patrónus-kliens viszonyok, amelyet korábban Hankiss Elemér szemléletesen „kvázi feudális kód”- nak nevezett (Hankiss 1989, 251.). A képzésen résztvevők többsége számára ezek a fejlemények nagy csalódást okoztak, s ennek következményei máig hatnak (Kovács et al. 2011).

Már a SAPARD képzést követően és a kísérleti LEADER program alatt nyilvánvalóvá vált, hogy a vidéki térségekben az egyenlőtlenségek nemcsak gazdaságiak, hanem alapvetően társadalmi jellegűek, amelyek megmutatkoztak az emberi erőforrások hatalmas különbségeiben, az érdekérvényesítési törekvések egyenlőtlenségeiben. Figyelembe kell vennünk a vidékfejlesztés sok esetben bizonytalan helyzetét is, mint például a LEADER program alulfinanszírozottságát, a gyakori átszervezéseket a minisztériumok között és azokon belül. Ezek a tényezők hallatlan mértékben megnehezítették a programban lévő potenciális előnyök kihasználását.

\section{A vidék fejlődését, fejlesztését gátló tényezőkről}

Az általános okok nagyon mélyre nyúlnak vissza, és a társadalom fejlődésének sajátos kevert (nyugati-keleti hibrid) jellegének hatására utalnak. Nagyot tévednénk, ha azt hinnénk, ez a körülmény gyorsan megváltoztatható, hiszen ebben az esetben komoly szakértők (Szücs Jenő, Hankiss Elemér, Hajnal István, Bibó István stb.) munkáit söpörnénk le az asztalról. Közelebbről szemlélve azt látjuk, hogy a történelemben szinte mindenhol, ahol a városok szerves úton fejlődtek, a vidék hátrányos helyzetbe került, de egy kompenzációs folyamat mérsékelte a legsúlyosabb problémákat. Sajnos a magyar történelmi folyamatok ezt nem tették lehetővé. A magyar városfejlődés nem tudta olyan mértékben támogatni a társadalom átformálódását, mint például Angliában vagy Észak-Olaszországban. A „kompenzációs folyamat” pedig teljesen elmaradt, s később sem valósult meg (lásd szocializmus), sőt ezzel éppen ellentétes politikai és gazdasági folyamatok mentek végbe. Az erőforrás-koncentráció intenzívvé vált, s ma is ez az alapvető tendencia. Ismét vissza kell térni oda, hogy a vidékfejlesztésről 
alkotott hivatalos hazai felfogás néhány évtizeddel lemaradt Európa és a tengeren túli vezető szellemi központoktól. Míg ott már régen eldőlt, hogy a szektoralapú (mezőgazdaságra alapozott) vidékfejlesztés zsákutca, addig nálunk még mindig erősen tartja magát ez a nézet. Így például megjelent a „mezőgazdasági vidékfejlesztés" fogalma, annak érdekében, hogy a források az ágazaton belül maradjanak. Természetesen nem vagyunk naivak, hiszen az EU-ban is ez a helyzet, amelyet egy kissé elken a hivatalos retorika. A mezőgazdasági érdekcsoportok itthon is sok esetben blokkolják a területi kezdeményezéseket.

A vidékfejlesztés szektoralapú megközelítése, legyen szó bármelyik szektorról, eleve magában hordozza a kudarcot. Ez különösen azokban a leszakadó, hátrányos helyzetű régiókban jelent gondot, ahol G. Fekete Éva is tevékenykedett. A vidékfejlesztés térségi alapú felfogása azért nem talál kellő támogatásra, mert (1) sokkal több anyagi eszközt köt le, mint például a szociális mezőgazdaság, (2) különböző érdekek egyeztetését kívánja meg, és sértheti a különböző szektorok érdekeit, (3) hosszú távú elgondolást igényel, amely nem népszerü azok körében, akik választástól választásig gondolkodnak.

További nagy problémának tartom, s ez különösen G. Fekete Éva számára volt keserü tapasztalat, hogy a vidékfejlesztéssel, a regionális fejlesztéssel foglalkozó tudományos körök tevékenysége valójában nem érte el a cselekvő politika ingerküszöbét. Ezt az ingerküszöböt még a mezőgazdaságot előtérbe helyező vidékfejlesztési csapat is alig lépte át, de a térségi alapú megközelítés tudományos kutatói még eddig se jutottak.

Gyakran hallhatjuk, hogy sajnos nincs elég pénz, s esetleg a jövőben még kevesebb lesz. Ez természetesen probléma, de nem kellene ebben az esetben átgondolni a rendelkezésre álló források elosztásának rendszerét? Vajon nem kellene azon elgondolkodni, hogy egyes vidéki térségek leszakadása miért nem állt meg 1990-óta? A területi egyenlőtlenségek minden országban jelen vannak, de az állam alacsony hatékonysága az esélykiegyenlítés területén már nem jellemző mindenhol.

Hasonlóan nagy nehézséget jelent a vidékfejlesztés számára a helyi közösségek állapota. Vidékfejlesztők, közösségfejlesztők igen nagy erőfeszítéseket tettek a helyzet megváltoztatása érdekében, amelyek sajnos többnyire eredménytelenek voltak, vagy az ígéretes eredmények nem bizonyultak tartósnak egyrészt a nem támogató (központi, helyi) intézményi környezet miatt, másrészt a helyi társadalom felkészületlensége következtében. Az a paradox helyzet állt elő, hogy a támogatások, az új ötletek, kezdeményezések elsősorban az átlagosnál jobb helyzetű vidéki terekben hasznosultak. Ez egyrészt a fejlettebb humán és kulturális erőforrások miatt történt, másrészt, ettől elválaszthatatlanul, e térségek hatékonyabb érdekérvényesítő képességének volt köszönhető. 


\section{A vidék fejlődésében tapasztalható eredményekről}

Minden fent vázolt probléma ellenére jelentős eredményeknek tartom a következőket:

- A vidékfejlesztő szakemberek új generációi nőttek fel, s tevékenységük nyomán jó példák sokasága született, ami akkor is nagy jelentőségü, ha a példák egyszerű másolása nem mindig célravezető. Maga a siker azonban komoly motivációs tényezőt jelenthet mások számára is. Szinte minden megyében találunk elkötelezett, felkészült embereket, mégis ki kell emelni Borsod-Abaúj-Zemplént, Zalát, Baranyát, Fejért, Szabolcs-Szatmárt.

- A vidékfejlesztés elfogadott kutatási területté vált a kutatóközpontokban, az egyetemeken, a politikában és az államigazgatásban. Természetesen tudjuk, hogy a vidékfejlesztés fogalma mögött eltérő felfogások, tudások húzódnak meg, de maga a téma napirendre került, és ma is ott van.

- Több olyan tudományos kategória, jelenség, fogalom vált elfogadottá, amelyek segítették a vidéki társadalom és gazdaság alakulásának értelmezését. Ilyenek például az endogenitás, a társadalmi innováció, az identitás, az együttműködés, a közösségfejlesztés, a szubszidiaritás, a szolidaritás fogalmai.

- Különböző források jelentek meg a vidékfejlesztésben, s ez még akkor is eredmény, ha mint korábban jeleztük, a rendelkezésre álló források és felhasználásuk nem minden esetben követik a kitűzött célokat.

- A vidéki térségek, települések közötti együttműködés eszméje kívánatos értékké vált, s ez akkor is eredmény, ha számos problémát ismerünk, ahogy erre például a LEADER program megvalósítását, valamint a vidékfejlesztési politika szektorközpontú irányultságát illetően utaltunk.

\section{A vidékfejlesztést szolgáló legeredményesebb módszerekről}

A legeredményesebb módszer a közösségalapú, helyi döntéseken, térségi együttmúködéseken alapuló fejlesztés. Lehet, hogy a kapcsolati tőkén alapuló, támogatásokat „kijáró” fejlesztés több pénzt hoz a térségbe, de ha nem harmonizál a helyi erőforrásrendszerrel, a helyi viszonyokkal, s nem valósul meg a szinergia, más szóval a valódi értelemben vett integrált vidékfejlesztés, akkor csak „katedrális épül a sivatagban", ahogy Bosworth és Atterton (2012) megjegyezték.

A legeredményesebb fejlesztési elképzelések a helyi társadalom és a humán erőforrások fejlesztésén alapulnak. Sajnos ebből van a legkevesebb, mert nem olyan látványos, s mert ezekben az esetekben nem lehet a „szalagot átvágni”. Ahogyan a vidékfejlesztési szakirodalom képviselői már jó pár évtizede megállapították, az eredményességet nem az inputon, hanem az outputon kell mérni. Éppen ez a probléma, hiszen a humán erőforrások és a társadalom fejlesztésének 
eredményei hosszú távon jelentkeznek, s sokszor nem azé a siker, aki a fejlesztést kezdeményezte.

Az endogenitás jelentőségét önmagában nem elég hangsúlyozni, mivel a fejlesztési folyamatok nemcsak vertikális kapcsolatrendszerben, de egyben horizontális dimenzióban is megvalósulnak. A "bottom-up" és a „top-down" dichotómia vagy-vagy értelmezése tehát nem írja le megfelelően a vidékfejlesztés kívánatos értékorientációját. A valóság túlmutat ezen a dichotómián, mivel a vidékfejlesztés horizontálisan is több szereplőt foglal magába, akik nem tartoznak a helyi társadalomba. Az „új-endogén” vidékfejlesztési elmélet (Shucksmith 2010; Bosworth, Atterton 2012) nem zárja ki a helyi közösségek és a helyi adottságok meghatározó szerepét, de kibővíti a szereplők és az intézmények körét elsősorban a nem hierarchikus kapcsolatban lévő társadalmi és gazdasági szereplőkkel, partner önkormányzatokkal, és egyben számol a nagy forrásközpontok (kormány, EU) segítségével is. Az elsőbbséget viszont a helyi társadalomnak és a horizontális kapcsolatokban résztvevő szereplőknek adja.

\section{Sikeresség, innováció - vidékfejlesztés}

A sikeresség és az innováció kapcsolata, bármennyire is kézenfekvőnek tűnik, nem magától értetődő. A vidékfejlesztés esetében a siker, egy település és térség sikeressége több úton érhető el. Sikeres lehet az a vidéki térség, amelyik döntően külső erőforrásokra támaszkodik, és a sikert a kapcsolati tőke hasznosításával éri el, de a fejlesztés egyúttal találkozik a helyi adottságokkal is. Ebben az esetben sokszor nem is tudni, mi a helyben megjelenő innováció, különösen a társadalmi innováció, amely a vidékfejlesztés terén döntő jelentőségü.

A sikeresség más oldalról a helyi közösségből (klubokból, öntevékeny csoportokból, egyesületekből, önkormányzati együttmúködésekből) kiinduló társadalmi innovációk hatékony alkalmazását jelenti. Ezek az innovációk nagyon sokfélék lehetnek, s nem feltétlenül attól függenek, hogy mennyi pénzt hoznak. Ha erősítik a helyi társadalmat, annak kohézióját, a szolidaritást, az identitást, akkor sikeresek minden közvetlen anyagi haszon nélkül is (Szörényiné 2016).

Már az 1960-as években nyilvánvalóvá vált, hogy az innovációk esetében a kulcskérdés az elfogadottság, a terjedés és az alkalmazás. A vidékfejlesztés területén a társadalmi innováció sikeressége a társadalmi beágyazottságtól függ. A társadalmi innováció sikere azon áll vagy bukik, hogy milyen valós szükségletekre irányul, vagy kelt életre az adott térségben.

A döntő kérdés a jó gyakorlatok átvételének szükségességét sokszor kellő átgondolás nélkül, szinte csak retorikai eszközként használó állásponttal kapcsolatban az eltérő kultúra és társadalmi berendezkedés hatása. A kívülről jövő innováció az új helyszínen eredeti formájában vagy múködik, vagy sem, vagy pedig az adaptáció során a helyi viszonyoknak megfelelően formálódik át. A máshol 
jól múködő gyakorlatok átvétele önmagában még nem garantálja a sikert. Különösen igaznak érzem ezt a megállapítást abban az esetben, amikor más országok eltérő helyzetű helyi társadalmaiban megvalósított sikereket próbálunk „átplántálni" egy másik kulturális közegbe. Az ilyen veszélyekre Chambers (1991) valamint Botes és Rensburg (2000) már régen figyelmeztettek, rámutatva azokra a típushibákra, amelyeket az adott társadalmat nem ismerő külföldi vidékfejlesztő szakértők, tanácsadók gyakran elkövetnek.

A vidékfejlesztés esetében nagyon jelentős a helyi kultúrára, helyi viszonyokra épülő társadalmi innováció, mert megvan a siker esélye, ami változtathat az adott vidéki település, térség helyzetén. A siker természetesen nem mindig következik be, s ennek többnyire szintén társadalmi okai vannak. Ha egyszer valaki átfogóan elemezné G. Fekete Éva hatalmas, köztük a Csereháton végzett munkásságát, a sikerekkel és kudarcokkal együtt, valószínűleg ugyanerre az eredményre jutna.

\section{A vidéki Magyarország fejlesztésének jó példái}

Az előzőekben már jeleztem, milyen fontos dimenziói lehetnek a sikeres vidékfejlesztésnek. Sok példát nem tudok mondani, fóként olyanokat nem, amelyek hosszabb távon is fennmaradtak, s életük nem a folyamatos külső támogatásoktól, anyagi injekciótól függött/függ. Azért is nehéz ilyen példákat mondani, mert a rendszeres monitorozás csak nagyon ritkán valósul meg, s a siker hosszabb távon érik be igazán. A Bódi Ferenc és Bőhm Antal által szerkesztett „Sikeres helyi társadalmak Magyarországon” című kötet írásai jól érzékeltetik a siker „sokféle arcát" a magyar vidéken (Bódi, Bőhm 2000). A kötet megjelenése óta eltelt két évtized a sikeres falvakkal kapcsolatos elképzeléseinket is megváltoztatta, így tehát helye van az újbóli tudományos vizsgálatoknak.

Ha mégis példát kellene mondanom, elsősorban Cserehátot (G. Fekete Éva kutatási és fejlesztési területe), a zalai „ZalA-KAR” kezdeményezést (Guitprechtné Molnár Erzsébet és Szederné Kummer Mária irányításával) és a belőle kinővő vidékfejlesztési törekvéseket, a mikrotérségi fejlesztéssé bővült alsómocsoládi példát (Dicső László vezetésével), vagy a mezőföldi kezdeményezéseket (Domokos Tamás és csapata) említhetem. Bizonyára több példa is akad, s elnézést kérek azoktól, akik kimaradtak! Fontos ugyanakkor, hogy csak a hosszú évek óta müködő, eredményes fejlesztések példáit, a hozzájuk kapcsolódó személyi és közösségi erőfeszítéseket említsük.

Végezetül: bár nem tudjuk pontosan, vagy talán sokféleképpen tudjuk, hogy mi a siker a vidékfejlesztésben, mivel az nagyrészt a térség helyzetétől, az ott élő emberektől függ, de az biztos, hogy a legapróbb jó kezdeményezés, amely a helyi társadalom kohézióját erősíti, vagy a társadalmi innovációk számára kedvező környezetet jelent, éppúgy sikerként könyvelhető el, mint egy eredményes turisztikai, infrastrukturális, kulturális, vagy szociális beruházás, fejlesztés. 


\section{Irodalom}

Bódi F., Bőhm A. (szerk.) (2000): Sikeres helyi társadalmak Magyarországon. Agroinform Kiadóház, Budapest

Botes, L., Rensburg, D. van (2000): Community participation in development: nine plagues and twelve commandments. Community Development Journal, 1., 41-58. https://doi.org/10.1093/cdj/ 35.1.41

Bosworth, G., Atterton, J. (2012): Entrepreneurial In-migration and Neo-endogenous Rural Development. Rural Sociology, 2., 254-277. https://doi.org/10.1111/j.1549-0831.2012.00079.x

Chambers, R. (1991): Rural Development. Putting the Last First. John Wiley \& Sons, New York

G. Fekete É. (2005): Új esély a perifériáknak? Falu, város, régió, 1-2., 44-46.

Hankiss E. (1989): Kelet európai alternatívák. Közgazdasági és Jogi Könyvkiadó, Budapest

Kovács D., Póla P., Finta I. (2011): A LEADER program és az alulról építkező vidékfejlesztés néhány tapasztalata Magyarországon. Gazdaság és Társadalom, 3-4., 81-108.

Kulcsár L. (szerk.) (1999): A SAPARD Előcsatlakozási programra felkészito” képzés tananyaga kistérségek számára. Scolar Kiadó, Budapest

Kulcsár, L., Jávor, K., Brown, D. (2003): Rural Policy in Hungary: Challenges Raised by the Prospects of EU Membership. European Rural Policy at the Crossroads International Conference. The Arkleton Centre for Rural Development Research, University of Aberdeen, Aberdeen

Nemes-Nagy J. (2017): Tér, függés, kohézió, hálózatok. Területi Statisztika, 1., 3-23. https://doi.org/ 10.15196/TS570101

Shucksmith, M. (2010): Disintegrated Rural Development? Neo-endogenous Rural Development, Planning and Place-Shaping in Diffused Power Contexts. Sociologia Ruralis, 1., https://doi.org/ 10.1111/j.1467-9523.2009.00497.x

Szörényiné Kukorelli I. (2016): Az innovációk szerepe a falvak életében. In: Sikos T. T., Tiner T. (szerk.): Tájak, régiók, települések térben és idóben. Tanulmánykötet Beluszky Pál 80. születésnapjára. Dialóg Campus Kiadó, Budapest, 417-428.

Uzzoli A., Szilágyi D. (2013): A nyugat-kelet és a centrum-periféria relációk a hazai egészségegyenlőtlenségek alakulásában az 1990 utáni válságok idején Magyarországon. Területi Statisztika, 4., 306-321. 